\title{
Molecular and serological prevalence of Anaplasma marginale in cattle of North Central Morocco
}

\author{
S. Ait Hamou ${ }^{\text {a,* }}$, T. Rahali a , H. Sahibi ${ }^{\text {a }}$ D. Belghyti ${ }^{\text {b }}$, B. Losson ${ }^{\text {c }}$, W. Goff ${ }^{\text {d }}$, A. Rhalem ${ }^{\text {a }}$ \\ a Département de Parasitologie et Maladies Parasitaires, Institut Agronomique et Vétérinaire Hassan II, B.P. 6202, Rabat-Instituts, Morocco \\ ${ }^{\mathrm{b}}$ Laboratoire de Biologie et Santé. Université Ibn Tofail, Kenitra, Morocco \\ ${ }^{\mathrm{c}}$ Laboratoire de Parasitologie et Maladies parasitaires, Faculté de médecine vétérinaire, Université de Liège, 4000, Liège, Belgium \\ ${ }^{\mathrm{d}}$ Animal Disease Research Unit, Agricultural Research Service, U.S. Department of Agriculture, Pullman, Washington, DC 99164-6630, United States
}

\section{A R T I C L E I N F O}

\section{Article history:}

Received 14 October 2011

Accepted 28 February 2012

\section{Keywords:}

Anaplasma marginale

Nested PCR

cELISA

Gharb

Saiss

Middle Atlas

Morocco

\begin{abstract}
A B S T R A C T
A cross sectional study was conducted to investigate the epidemiological distribution of Anaplasma marginale in North Central Morocco. Blood samples from five provinces of Morocco were collected from apparently healthy cattle $(n=668)$ and simultaneously analyzed by a nested polymerase chain reaction (nPCR) assay and competitive enzyme-linked immunosorbent assay (cELISA). The overall prevalence of A. marginale was $21.9 \%$ by nPCR and $16.5 \%$ by cELISA. The Kappa coefficient between nPCR and cELISA indicated a modest level of agreement (0.54). The prevalence of $A$. marginale varied significantly according to the province and the month of sampling. However age, gender and breed did not have a significant effect on the prevalence of this pathogen. The highest prevalence of A. marginale was found in the Gharb, a sub-humid area while the lowest was reported in the Saiss, a semi-arid area. These results indicate that an $A$. marginale infection are widespread in the country and suggests that either or both techniques are excellent tools for epidemiological studies and control programs.
\end{abstract}

(c) 2012 Elsevier Ltd. All rights reserved.

\section{Introduction}

Bovine anaplasmosis is a hemoparasitic disease caused by the tick-borne pathogen Anaplasma marginale (Dumler et al., 2001) and Anaplasma centrale (Inokuma et al., 2001). Anaplasma is globally the most prevalent tick-borne pathogen of cattle and has a worldwide distribution with regions of endemicity on six continents (Futse et al., 2003) and high incidence in tropical and subtropical regions of the world (De La Fuente et al., 2005; Torina et al., 2008; Gokce et al., 2008; Ooshiro et al., 2009; Ruybal et al., 2009). A. centrale is widely distributed but has never been reported in North Africa, it has been reported only in South Africa (OIE, 2008). However, the geographic distribution depends largely on the distribution and density of the reservoir hosts and tick vectors (Ogden et al., 2002).

Biological transmission of $A$. marginale is effected by ticks and approximately 20 species of ticks have been incriminated as vectors worldwide, including Boophilus spp., Rhipicephalus spp., Hyalomma spp., Demacentor spp. and Ixodes spp. (Uilenberg, 1995; De Waal et al., 2000; Jongejan and Uilenberg, 2004; Kocan et al., 2004). Tick transmissibility of Anaplasma is complex and ranges from very efficient transmission to non-transmission re-

\footnotetext{
* Corresponding author. Tel.: +212 670811822; fax: +212 0537775845 .

E-mail address: aitsana@hotmail.com (S. Ait Hamou).
}

lated to both Anaplasma strains as well as species of tick (Ueti et al., 2007). In Morocco, the vector competency of local tick species for transmitting $A$. marginale has yet to be demonstrated.

Following transmission, cattle develop rickettsiaemia, accompanied by fever, severe anemia, weight loss, decreased milk production, abortion and sometimes death during acute infections (Kocan et al., 2003; Urdaz-Rodríguez et al., 2009). After the first infection with $A$. marginale, cattle remain persistently infected carriers and serve as long-term reservoirs for the maintenance of the infection in ticks (Goff et al., 1988; Kocan et al., 1992a,b; Eriks et al., 1993). Anaplasmosis has been reported in different regions of Morocco (Verhulst et al., 1983; Sahibi et al., 1998b), but it has a perceived lower incidence compared with theileriosis and babesiosis. Although, severe economic losses have been reported due to anaplasmosis outbreaks in several parts of the world (Herrero et al., 1998; Kocan et al., 2000, 2004; Grisi et al., 2002; Jongejan and Uilenberg, 2004), no specific disease outbreak of $A$. marginale in cattle has been reported in Morocco and the only epidemiological studies of anaplasmosis reported previously were conducted more than a decade ago (Sahibi et al., 1998b).

Diagnosis of the disease is usually based on microscopic examination of stained blood films; however this method can only detect levels of $10^{6}$ infected erythrocytes per ml (Gale et al., 1996) in acute infection but it is not sufficiently sensitive or specific to detect chronic carriers. A cELISA was developed based on antibody 
binding to recombinant $A$. marginale major surface protein 5 (msp5) (Knowles et al., 1996). Msp5 is a protein conserved among Anaplasma spp. This assay was used to detect both acute and chronic A. marginale and A. centrale infections in cattle (Knowles et al., 1996), A. ovis infections in goats (Ndung'u et al., 1995) and sheep and wildlife (Scoles et al., 2008). Recently, molecular methods based on nucleic acids such as nPCR offer greater sensitivity and specificity over the existing diagnostic tests (Torioni de Echaide et al., 1998). Consequently a combined nPCR/cELISA approach could provide powerful tools for epidemiological investigations with high accuracy in the diagnosis of Anaplasma infections. Successful management of anaplasmosis in cattle depends on adequate knowledge of prevalence for $A$. marginale and the risk factors associated with transmission (Alonso et al., 1992; Swai et al., 2005). The aim of this study was to determine the prevalence and risk factors of anaplasmosis by cELISA and nPCR. This study formed a part of an epidemiological survey of selected tick-borne diseases in five provinces of Morocco.

\section{Materials and methods}

\subsection{Area of study}

A cross sectional study was carried out between March and August 2005 in five provinces of North Central Morocco: Kénitra $\left(34^{\circ} 15^{\prime} \mathrm{N} 6^{\circ} 35^{\prime} \mathrm{W}\right)$, Sidi Slimane $\left(34^{\circ} 13^{\prime} \mathrm{N} 5^{\circ} 42^{\prime} \mathrm{W}\right)$, Sidi Kacem $\left(34^{\circ} 13^{\prime} \mathrm{N} 5^{\circ} 42^{\prime} \mathrm{W}\right)$, Meknes $\left(33^{\circ} 53^{\prime} \mathrm{N} 5^{\circ} 33^{\prime} \mathrm{W}\right)$ and El Hajeb $\left(3351^{\prime} \mathrm{N} 702^{\prime} \mathrm{W}\right.$ ). These study areas belong to three ecological zones: Gharb, Saiss and Middle Atlas (Fig. 1).

\subsubsection{Region of Gharb}

This region includes Kénitra, Sidi Slimane and Sidi Kacem provinces.

Kénitra province is located at an altitude of $25 \mathrm{~m}$ and has a subhumid climate with a mean annual rainfall of $600 \mathrm{~mm}$. The minimum average temperature of the coldest month is about $5{ }^{\circ} \mathrm{C}$ and the maximum average temperature of the hottest month is about $30^{\circ} \mathrm{C}$.

Sidi Slimane is located at an altitude of $41 \mathrm{~m}$, and has a semiarid climate with a mean annual rainfall of $500 \mathrm{~mm}$. The minimum average temperature of the coldest month is about $4{ }^{\circ} \mathrm{C}$ and the maximum average temperature of the hottest month is about $35^{\circ} \mathrm{C}$.

Sidi Kacem is located at an altitude of $74 \mathrm{~m}$, and has a semi-arid climate with a mean annual rainfall of $500 \mathrm{~mm}$. The minimum average temperature of the coldest month is about $5{ }^{\circ} \mathrm{C}$ and the maximum average temperature of the hottest month is about $35^{\circ} \mathrm{C}$.

\subsubsection{Region of Saiss}

This region includes Meknes province which ranges from 145 to $549 \mathrm{~m}$ in altitude and has a semi-arid climate with a mean annual rainfall of $545 \mathrm{~mm}$. The minimum average temperature of the coldest month is $4{ }^{\circ} \mathrm{C}$ and the maximum average temperature of the hottest month is about $35^{\circ} \mathrm{C}$

\subsubsection{Region of the Middle Atlas}

This region includes El Hajeb province where the climate is humid with cold winters in the higher elevations. The effect of altitude (about $1200 \mathrm{~m}$ ) decreases the temperatures: winter is very cold, summer is moderate. Rainfall is about $1200 \mathrm{~mm}$, and occurs between October and April. From May to September the weather is hot and dry with a minimum average temperature of the coldest month of about $-4{ }^{\circ} \mathrm{C}$ and the maximum average temperature of the hottest month of about $30^{\circ} \mathrm{C}$.

The farmers in these regions practice an agro-pastoral farming system which is the main source of milk and meat consumed in Morocco (Guessous, 1991). Hyalomma detritum, Hyalomma marginatum, and Rhipicephalus (Boophilus) annulatus are the major tick species of economic importance in the study area (El Kamch, 2005).

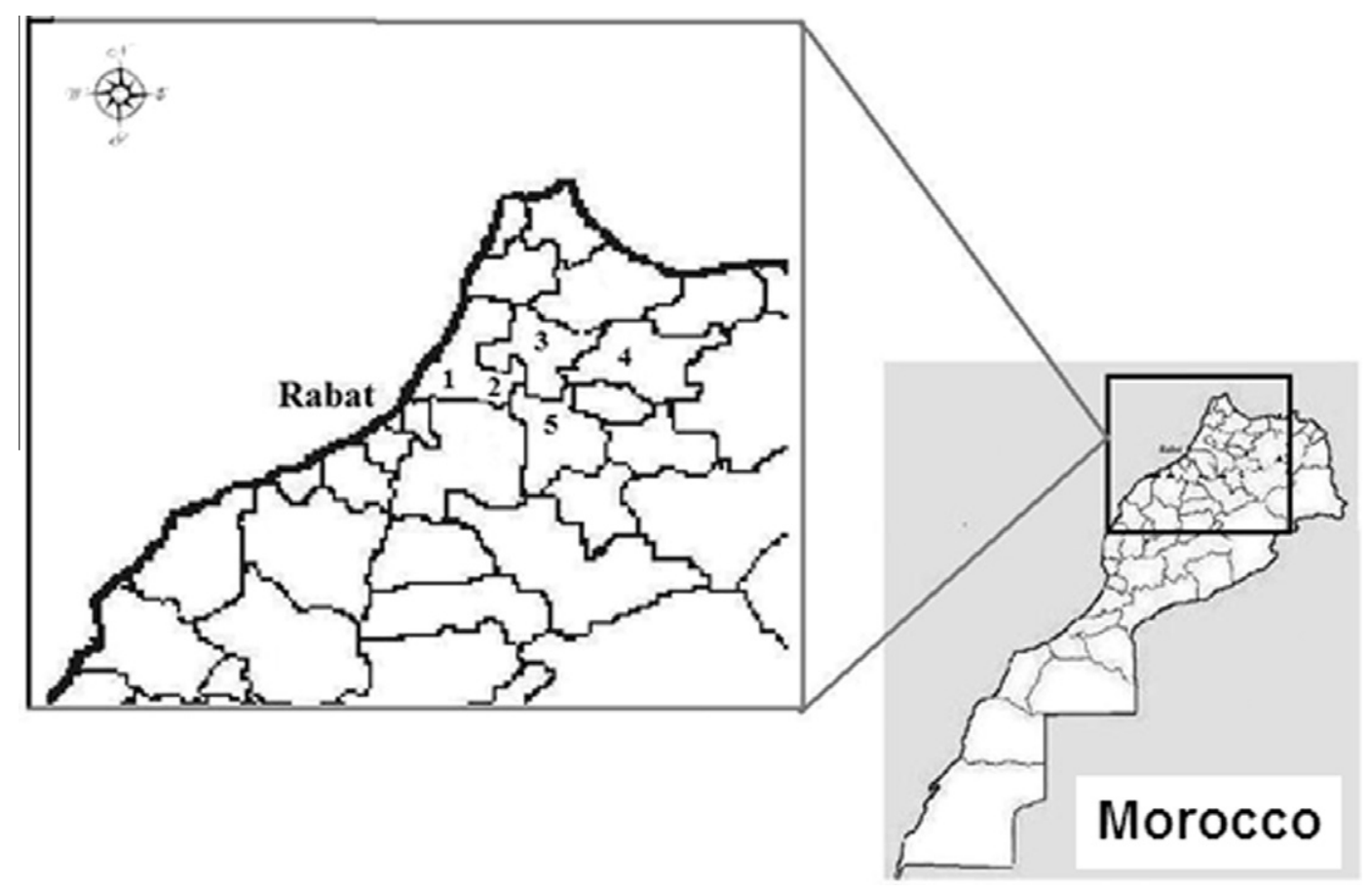

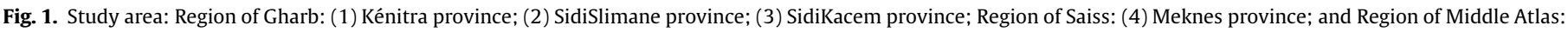
(5) El Hajeb province. 


\subsection{Collection of blood samples}

Farms were visited twice a month in each site and a total of 668 cattle were randomly sampled (252 males and 416 females). Cattle sera were collected from various breeds, which included local (39.7\%), imported (24.1\%) and cross-breed (36.2\%).

Blood was collected into sterile tubes with and without anticoagulant (EDTA) and maintained at $4{ }^{\circ} \mathrm{C}$ until arrival at the laboratory. Serum was separated, and serum and whole blood were stored at $-20^{\circ} \mathrm{C}$.

\subsection{Anaplasmosis serological test}

The anaplasmosis cELISA was performed using the Anaplasma Antibody Test Kit, cELISA from VMRD Inc. (Pullman, WA, USA) following the manufacturer's instructions. This assay detects serum antibodies against the Msp5 protein of Anaplasma spp. (Knowles et al., 1996).

\subsection{DNA extraction}

Blood collected on EDTA was washed three times with PBS buffer to remove the leukocyte layer. The resulting red blood cell mass was processed to extract the DNA according to the manufacturer's recommendations (Puregene kit Gentra Systems Inc.). The extracted DNA was kept refrigerated $\left(4^{\circ} \mathrm{C}\right)$ until the nPCR analysis was carried out

\subsection{Nested PCR}

The nPCR was performed on the extracted DNA by using primers specific for the msp5 gene as described by Torioni de Echaide et al. (1998). Msp5 was amplified using the following primers: external forward $5^{\prime}$-GCATAGCCTCCGCGTCTTTC- $3^{\prime}$ and external reverse $5^{\prime}$-TCCTCGCCTTGGCCCTCAGA- $3^{\prime}$ and the internal forward primer 5'-TACACGTGCCCTACCGAGTTA-3'. Both reactions were performed under the same cycling conditions with a GeneAmp 2400 system (Applied Biosystems Inc.) beginning with a hot start for $3 \mathrm{~min}$ at $95^{\circ} \mathrm{C}$ followed by 35 cycles with denaturation for $30 \mathrm{~s}$ at $95{ }^{\circ} \mathrm{C}$, annealing for $58 \mathrm{~s}$ at $65^{\circ} \mathrm{C}$, and extension for $30 \mathrm{~s}$ at $72{ }^{\circ} \mathrm{C}$ and a final extension for $10 \mathrm{~min}$ at $72{ }^{\circ} \mathrm{C}$. The product of the primary PCR was then run under the same conditions for an additional 35 cycles with the appropriate primers for the secondary PCR. Genomic DNA of $A$. marginale was isolated from infected blood showing high rickettsiaemia during blood smear examination and utilized as a positive control. Blood from Cattle shown to be free of $A$. marginale by subinoculation of a blood sample into a splenectomized calf was used as a negative control. Controls were also subjected to the same treatment.

Products were visualized in a $1.5 \%$ agarose gel containing ethidium bromide and visualized by UV transillumination. A 457-bp band is expected after the primary PCR and a 345-bp band is expected after nested PCR. The 345-bp expected DNA fragment was identified by comparison with 100 base pair incremental molecular markers (100 bp Ladder, Gibco BRL) (Fig. 2).

\subsection{Statistical analysis}

Data files were entered, edited and performed on Epi-Info 2007 (version 3.4). Bivariant analysis was used to assess the relationship between Anaplasma seropositive animals and the risk factors responsible for the infection. The chi-square test was used to evaluate significant differences of infection rate in animals of different gender, age, season and location. $P$ values for significance were set at $P \leqslant 0.05$. The kappa coefficient was calculated to evaluate the degree of agreement between the nPCR assay and cELISA.

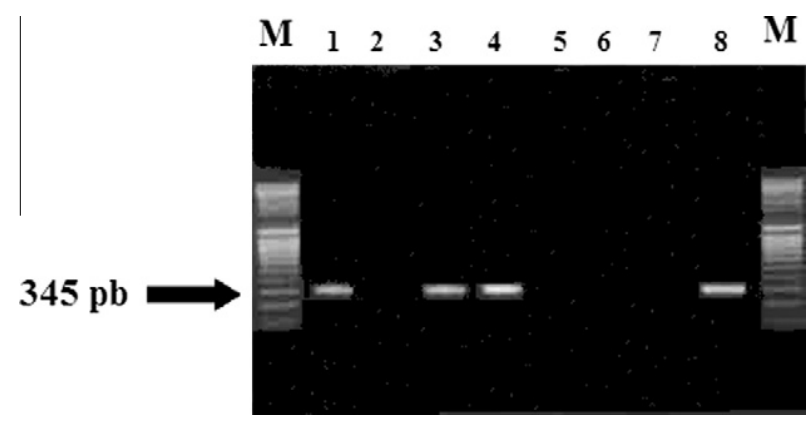

Fig. 2. Agarose-gel electrophoresis of amplification product obtained from Anaplasma marginale using Anaplasma specific primers. Lines M: molecular weight (100bps); line 1-3 and 4: blood from positive cattle; line 2-5 and 6: blood from negative cattle; line 7: negative control; line 8: positive control.

\section{Results}

During a period of five months, 668 cattle blood samples (252 male and 416 female) were randomly collected from the five different provinces identified above in North Central Morocco and simultaneously analyzed by nPCR and cELISA techniques. The mean age was $17.48 \pm 11.03$ months and the sex ratio (male/female) was 0.60 .

When the two assays were compared, there was an $85.6 \%$ concordance with 81 samples positive and 491 samples were negative by both assays (Table 1 ). The cELISA identified 112 positive samples or a prevalence rate of $16.8 \%$ while the nPCR identified 146 positive samples or a prevalence of $21.9 \%$ (Table 1 ). Sixty-five samples were nPCR positive and serologically negative and 31 samples were serologically positive and nPCR negative.

Although there was an $85.6 \%$ concordance, nPCR detected higher positive rates of the parasite than the cELISA. The kappa value was fairly low (0.54) (Table 1 ).

The prevalence rate in North Central Morocco may be as high as $26.5 \%$ using the total number of samples that were positive for either test. The prevalence of bovine anaplasmosis in different cattle populations was compared on the basis of different age, gender, breed, month, climate and province again using the total number of samples positive for either test (Fig. 3 ). There was no statistically significant association for the prevalence of $A$. marginale among different age groups $\left(X^{2}=0.59, P>0.05\right)$, and no significant difference observed between gender $\left(X^{2}=0.34, P>0.05\right)$ nor breed $\left(X^{2}=0.82, P>0.05\right)$ of cattle. The highest prevalence of $A$. marginale was observed in Kenitra with $52 \%$, which was significantly higher compared with the other sites $\left(X^{2}=78.22, P<0.05\right)$. Furthermore, there were statistically significant differences between the climates and prevalence of $A$. marginale. The infection rates of A. marginale was significantly higher in August and June compared to other months $\left(X^{2}=28.27, P>0.05\right)$ (Fig. 3).

\section{Discussion}

Despite the fact that several studies have reported on the presence of tick-borne diseases in Morocco (Ouhelli and Flach, 1990; Sahibi et al., 1998a, 1998b; El Haj et al., 2002; Sahibi and Rhalem, 2007), there is still little information about the prevalence of anaplasmosis. In this study we investigated the epidemiology of A. marginale infections in cattle from five provinces of North Central Morocco using the nPCR and cELISA. The results clearly indicated the presence of $A$. marginale infection in this region of the country with an overall prevalence of $26.5 \%$. A few previous serological studies involving $A$. marginale reported that the seroprevalence ranged from $9 \%$ to $22.2 \%$ in different regions of Morocco 
Table 1

Summary of the molecular and serological detection of A marginale using the nPCR assay and cELISA among 668 cattle sampled in North Central Morocco.

\begin{tabular}{|c|c|c|c|c|c|c|c|}
\hline \multirow[t]{2}{*}{$\mathrm{nPCR}^{\mathrm{a}}$} & \multicolumn{4}{|c|}{ cELISA $^{\mathrm{b}}$} & \multirow[t]{2}{*}{ Total } & \multirow[t]{2}{*}{ PCR/cELISA ${ }^{\mathrm{c}}$} & \multirow[t]{2}{*}{$\%$ Agreement $^{\mathrm{d}}$ (Kappa value) } \\
\hline & \multicolumn{2}{|c|}{ Positive (\%) } & \multicolumn{2}{|c|}{ Négative (\%) } & & & \\
\hline Positive & 81 & $(72,3)$ & 65 & $(11,7)$ & 146 & 177 & $85.6(0,54)$ \\
\hline Négative & 31 & $(27,7)$ & 491 & $(88,3)$ & 522 & 491 & \\
\hline Total & 112 & & 556 & & & 668 & \\
\hline
\end{tabular}

a The frequency of positive and negative samples as results of nPCR.

b The frequency of positive and negative samples as result of cELISA cross - tabulated with nPCR.

c The frequency of positive and negative samples of combined nPCR and ELISA.

d Concordance between nPCR and cELISA results.
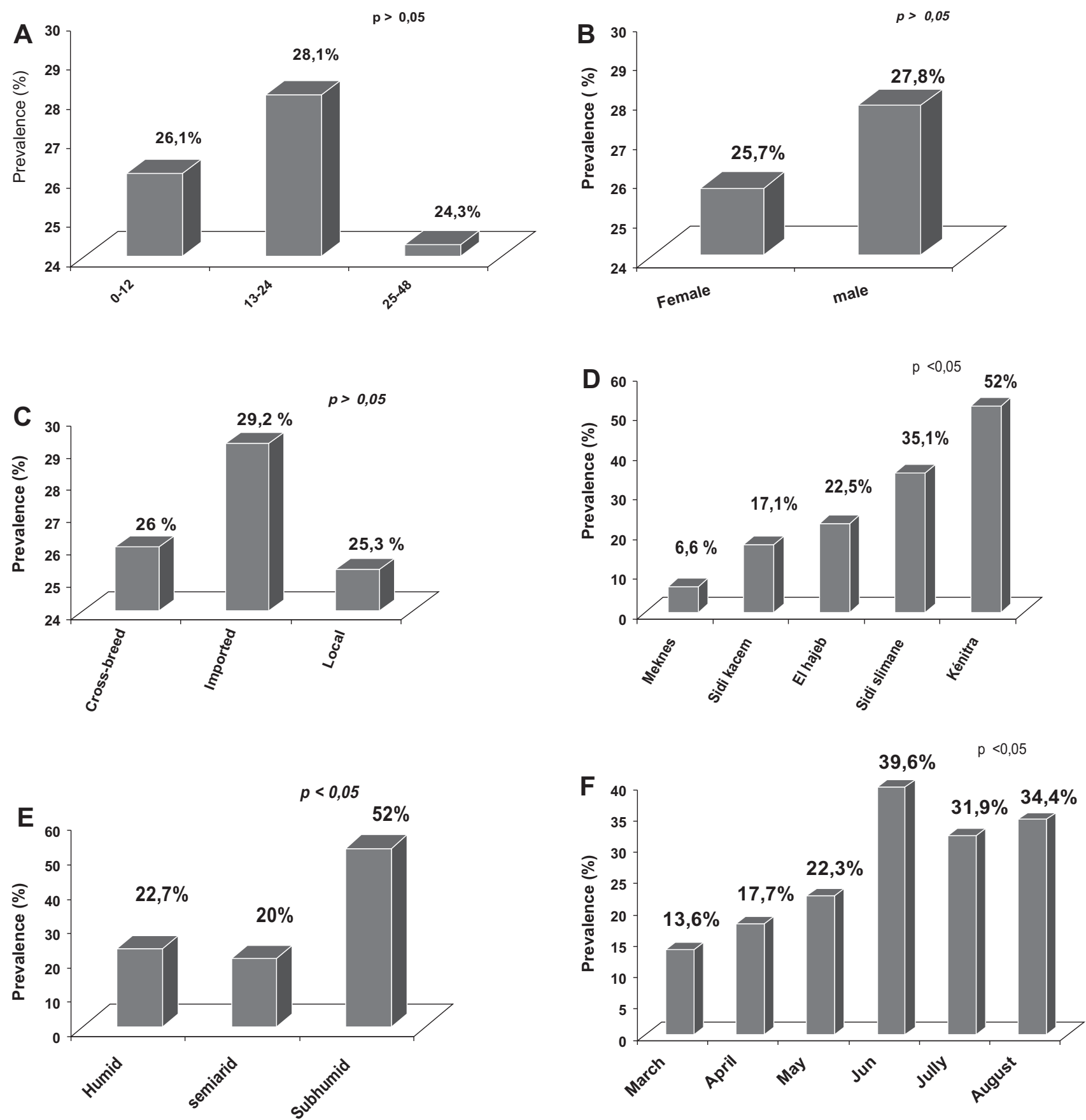

Fig. 3. Comparison of the overall prevalence of A. marginale on the basis of age (A), gender (B), breed (C), provinces (D), climate (E) and month of sampling (F). 
(Verhulst et al., 1983; Sahibi et al., 1998b; Sahibi and Rhalem, 2007). Compared to other North African Mediterranean countries, the prevalence in Morocco remains higher than those observed in Algeria 7.4\% (Ziam and Benaouf, 2004) and in Egypt 3.5\% (Younis et al., 2009). Moreover, our finding was similar to that observed in Puerto Rico with 27.4\% (Urdaz-Rodríguez et al., 2009) and Tanzania (37.2\%) (Swai et al., 2005). In other regions anaplasmosis prevalence occurs at much higher levels i.e. in Kenya (89\%) (Maloo et al., 2001), El Salvador (78.5\%) (Payne and Scott, 1982) and St. Lucia (70\%) (Hugh-Jones et al., 1988). However, prevalence rates reported for countries must be taken with caution since a standardized assay as sampling procedure was not used in each study and rates of infection may vary even among neighboring farms (Stuen et al., 2002).

The prevalence of Anaplasma infection is affected by the geographic situation and other risk factors. In our study, we investigated the relationship between risk factors such as age, gender and different breeds, but only the province, climate and month of sampling demonstrated significant effects. The positive animals were found in all provinces investigated during the period of survey. The highest prevalence of $A$. marginale was observed in Kenitra (52\%) in contrast to previous reports of $10.6 \%$ (Sahibi et al., 1998b). In the current study a lower prevalence was reported in Meknes (Saiss) with $6.6 \%$ which is similar to the previous report of $9 \%$ in the same area (Sahibi et al., 1998b).

In general, seropositivity in cattle decreased while going from the Gharb toward the Middle Atlas regions suggesting that the change of climate and vegetation cover are important factors limiting the development of the tick vectors. This result was expected as it is in agreement with described geographic tick distribution in the region (Sahibi and Rhalem, 2007).This result is also supported by the fact that Rhipicephalus (Boophilus) annulatus is a known vector of A. marginale (Scoles et al., 2008) and its prevalence in the Gharb region is 34\% (Sahibi and Rhalem, 2007). This tick species is far less abundant in Saiss and Middle Atlas (El Kamch, 2005). In the current study, the sub-humid climate zone showed the highest percentage of infected cattle $(64 / 123,52 \%)$. The semi-arid climate of Meknes showed the lowest prevalence (6\%). However in the province of Sidi Slimane with a similar climate, A. marginale prevalence was $35.1 \%$. Thus, the significant differences in prevalence cannot be explained strictly by ecology or the dynamics of the tick population in the different zones. Other components such as immunity level, tick control practices, tick species and grazing system are likely to play a role as well.

In all areas there was a clear pattern of increased numbers of positive samples during the summer season (June, July and August) which likely corresponds with increased tick activity in the preceding months. Vector populations are associated with many factors of which climate, season and host availability are probably the most important.

There is no certainty that there is an absence of clinical signs of anaplasmosis in this area since diagnosis based on nonspecific clinical signs (fever and anemia) could lead to misdiagnosis with other diseases, such as babesiosis and theileriosis. However, practitioners in the region have not reported what they think to be clinical anaplasmosis.

If this is the case, a long-term endemicity of infection may be present in the studied areas with a substantial frequency of asymptomatic chronic carriers.

The overall prevalence of $A$. marginale infections was compared among different cattle on the basis of age gender and breed. Somewhat surprising, there was no significant difference in age, in contrast to a previous study from Sudan (Awad et al., 2011). Cattle of all ages are susceptible to anaplasmosis but the severity of the infection is directly related to age, with older animals suffering more severe clinical disease. Indeed, in this survey prevalence in young animals was similar to older animals consistent with previous reports in Costa Rica (Pérez et al., 1994; Herrero et al., 1998) and Brazil (Barros et al., 2005). Young animals probably become infected early, develop immunity and serve as reservoirs of infection for other animals (Herrero et al., 1998).

Our study did reveal a slightly higher prevalence of infection in imported cattle compared with cross bred and autochthones breeds. Although not significantly different in this study, it is in agreement with other studies (Knowles et al., 1982; Sahibi et al., 1998b). These results suggest the necessity for further study to investigate the effect of geographic distribution of vector ticks, farm management in the surveyed areas and what role may be played by imported cattle.

In this study, nPCR detected a higher number of infected animals than the cELISA. These discrepancies could be explained by differences in the timing of the parasite presence and the antibody responses in the infected animals as well as the stage of infection. During chronic infection antibodies remain in the circulating blood for a longer period even after a decrease in parasitemia below detection even by PCR or after parasite clearance (Herrero et al., 1998). Conversely, samples positive by nPCR and negative by serology most likely represent recent infection prior to the development of antibody.

\section{Conclusion}

This is the first epidemiologic study investigating the occurrence of $A$. marginale in cattle in North Central Morocco using both molecular and serologic tests. The data provide important information about the incidence of $A$. marginale infection and the use of these techniques will be useful when planning management and control programs for this disease in Morocco.

\section{Conflicts of interest statement}

None of the authors of this paper has a financial or personal relationship with other people or organizations that could inappropriately influence or bias the content of the paper.

\section{Acknowledgments}

Financial support for this work was provided by PIC-CUD Project MA 6441, Belgium and FRAB 01/001 \& 2/2500/1 projects.

The authors would like to thank the Department of Parasitology ULg. Liège, Belgium for transfer of technology: Serology and Molecular biology.

\section{References}

Alonso, M., Arellano-Sota, C., Cereser, V.H., Cordoves, C.O., Guglielmone, A.A Kessler, R.H., Mangold, A.J., Nari, A., Patarroyo, J.H., Solari, M.A., 1992 Epidemiology of bovine anaplasmosis and babesiosis in Latin America and the Caribbean. Revue Scientifique et Technique 11, 713-733.

Awad, H., Antunes, S., Galindo, R.C., do Rosario, V.E., De La Fuente, J., Domingos, A., El Hussein, A.M., 2011. Prevalence and genetic diversity of Babesia and Anaplasma species in cattle in Sudan. Veterinary Parasitology (Epub ahead of print).

Barros, S.L., Madruga, C.R., Araújo, F.R., Menk, C.F., de Almeida, M.A.O., Melo, E.P.S. Kessler, R.H., 2005. Serological survey of Babesia bovis, Babesia bigemina, and Anaplasma marginale antibodies in cattle from the semi-arid region of the state of Bahia, Brazil, by enzyme-linked immunosorbent assays. Memorias do Instituto Oswaldo Cruz 100, 613-617.

De La Fuente, J., Torina, A., Caracappa, S., Tumino, G., Furla, R., Almazan, C., Kocan, K.M., 2005. Serologic and molecular characterization of Anaplasma species infection in farm animals and ticks from Sicily. Veterinary Parasitology 133, 357-362.

De Waal, D.T., Matthee, O., Jongejan, F., 2000. Evaluation of the MAP1b ELISA for the diagnosis of heartwater in South Africa. Annals of the New York Academy of Sciences 916, 622-627.

Dumler, J.S., Barbet, A.F., Bekker, C.P.J., Dasch, G.A., Palmer, G.H., Ray, S.C., Rikihisa, Y., Rurangirwa, F.R., 2001. Reorganization of the genera in the family's 
Rickettsiaceae and Anaplasmataceae in the order Rickettsiales: unification of some species of Ehrlichia with Anaplasma, Cowdria with Ehrlichia and Ehrlichia with Neorickettsia, descriptions of six new species combinations and designation of Ehrlichia equi and "HGE agent" as subjective synonyms of Ehrlichia phagocytophila. International Journal of Systematic and Evolutionary Microbiology 51, 2145-2165.

El Haj, N., Kachani, M., Bouslikhane, M., Ouhelli, H., Ahami, A.T., Katende, J. Morzaria, S.P., 2002. Seroepidemiologie de la theileriose et de la babesiose au Maroc. Revue de Médecine Vétérinaire 153, 809-814.

El Kamch, S., 2005. Séroprévalence des hémoparasitoses vectorielles des bovins dans la région du Centre Nord du Maroc. Thèse Doctorat Vétérinaire I.A.V. Hassan II, Rabat, pp. 115.

Eriks, I.S., Stiller, D., Palmer, G.H., 1993. Impact of persistent Anaplasma marginale rickettsemia on tick infection and transmission. Journal of Clinical Microbiology 31, 2091-2096.

Futse, J.E., Ueti, M.W., Knowles, D.P., Palmer, G.H., 2003. Transmission of Anaplasma marginale by Boophilus microplus: retention of vector competence in the absence of vector-pathogen interaction. Journal of Clinical Microbiology 41, 3829-3834.

Gale, K.R., Dimmock, C.M., Gartside, M., Leatch, G., 1996. Anaplasma marginale: detection of carrier cattle by PCR. International Journal for Parasitology 26 1103-1109.

Goff, W.L., Barbet, A.F., Stiller, D., Palmer, G.H., Knowles, D.P., Kocan, K.M., Gorham, J.R., McGuire, T.C., 1988. Detection of Anaplasma marginale-infected tick vectors by using a cloned DNA probe. Proceedings of the National academy of Sciences of the United States of America 85, 919-923.

Gokce, H.I., Genc, O., Akca, A., Vatansever, Z., Unver, A., Erdogan, H.M., 2008 Molecular and serological evidence of Anaplasma phagocytophilum infection of farm animals in the Black Sea Region of Turkey. Acta Veterinaria Hungarica 56, 281-292.

Grisi, L., Massard, C.L., Borja, G.E.M., Pereira, J.B., 2002. Impacto econômico das principais ectoparasitoses em bovinos no Brasil. Hora Veterinária 21, 8-10.

Guessous, F., 1991. Production Fourragère et Systèmes Animaux, Plan Directeur Fourrager (MOR/87/001). Rapport de Synthèse, Actes Editions, pp. 118.

Herrero, M.V., Perez, E., Goff, W.L., Torioni de Echaide, S., Knowles, D.P., McElwain, T.F., Alvarez, V., Alvarez, A., Buening, G.M., 1998. Prospective study for the detection of Anaplasma marginale Theiler, 1911 (Rickettsiales: Anaplasmataceae) in Coasta Rica. Annals of the New York Academy of Sciences 849, 226-233.

Hugh-Jones, M.E., Scotland, K., Applewhaite, L.M., Alexander, M., 1988 Seroprevalence of anaplasmosis in livestock on St. Lucia, 1983. Tropica Animal Health and Production 20, 137-139.

Inokuma, H., Terada, Y., Kamio, T., Raoult, D., Brouqui, P., 2001. Analysis of the 16S rRNA gene sequence of Anaplasma centrale and its phylo-genetic relatedness to other ehrlichiae. Clinical and Diagnostic Laboratory Immunology 8, 241-244.

Jongejan, F., Uilenberg, G., 2004. The global importance of ticks. Parasitology 129 (Suppl.), S3-S14.

Knowles, R.T., Montrose, M., Craig, T.M., Wagner, G.G., Long, R.F., 1982. Clinical and serological evidence of bovine babesiosis and anaplasmosis in St. Lucia. Veterinary Parasitology 10, 307-311.

Knowles, D.P., Torioni De Echaide, S., Palmer, G.H., McGuire, T.C., Stiller, D. McElwain, T.F., 1996. Antibody against an Anaplasma marginale MSP5 epitope common to tick and erythrocyte stages identifies persistently infected cattle. Journal of Clinical Microbiology 34, 2225-2230.

Kocan, K.M Stiller, D Goff, W.L, Claypool, P.L, Edwards, W Ewing S.A., McGuire, T.C., Hair, J.A., Barron, S.J., 1992a. Development of Anaplasma marginale in male Dermacentor andersoni transferred from parasitemic to susceptible cattle. American Journal of Veterinary Medicine 53, 499-507.

Kocan, K.M., Goff, W.L., Stiller, D., Claypool, P.L., Edwards, W., Ewing, S.A., Hair, J.A., Barron, S.J., 1992b. Persistence of Anaplasma marginale (Rickettsiales: Anaplasmataceae) in male Dermacentor andersoni (Acari: Ixodidae) transferred successively from infected to susceptible calves. Journal of Medical Entomology 29, 657-668.

Kocan, K.M., Blouin, E.F., Barbet, A.F., 2000. Anaplasmosis control: past, present, and future. Annals of the New York Academy of Sciences 916, 501-509.

Kocan, K.M. De La Fuente, J., Guglielmone, A.A., Melendéz, R.D., 2003. Antigens and alternatives for control of Anaplasma marginale infection in cattle. Clinical Microbiology Reviews 16, 698-712.

Kocan, K.M. de la Fuente, J., Blouin, E.F. Garcia-Garcia, J.C. 2004. Anaplasm marginale (Rickettsiales: Anaplasmataceae): recent advances in defining hostpathogen adaptations of a tick-borne rickettsia. Parasitology 129 (Suppl.), 285300.

Maloo, S.H., Rowlands, G.J., Thorpe, W., Gettinby, G., Perry, B.D., 2001. A longitudinal study of disease incidence and case-fatality risks on small-holder dairy farms in coastal Kenya. Preventive Veterinary Medicine 52, 17-29.

Ndung'u, L., Aguirre, W.C., Rurangirwa, F.R., McElwain, T.F., McGuire, T.C., Knowles, D.P., Palmer, G.H., 1995. Detection of Anaplasma ovis infection in goats by major surface protein-5 competitive inhibition enzyme-linked immunosorbent assay. Journal of Clinical Microbiology 33, 675-679.

Ogden, N.H., Casey, A.N.J., French, N.P., Adams, J.D.W., Woldehiwet, Z., 2002. Field evidence for density-dependent facilitation amongst Ixodes ricinus ticks feeding on sheep. Parasitology 124, 117-125.

Ooshiro, M., Zakimi, S., Matsukawa, Y., Ysfuso, M., Katagiri, Y., Inokuma, H., 2009. Anaplasma marginale infection in a Japanese Black cow 13 years after eradication of Rhipicephalus (Boophilus) microplus in Okinawa, Japan. Veterinary Parasitology 160, 351-355.

Ouhelli, H., Flach, E., 1990. Epidemiology and control of theileriosis in Morocco: recent developments in the research and control of Theileria annulata. In: Dolan, T.T. (Ed.), Proceedings of a Workshop held at ILRAD, 17-19 September, Nairobi, Kenya, pp. 19-20.

Payne, R.C., Scott, J.M., 1982. Anaplasmosis and babesiosis in El Salvador. Tropical Animal Health and Production 14, 75-80.

Pérez, E., Herrero, M.V., Jiménez, C., Hird, D., Buening, G.B., 1994. Effect of management and host factors on seroprevalence of bovine anaplasmosis and babesiosis in Costa Rica. Preventive Veterinary Medicine 20, 33-46.

Ruybal, P., Moretta, R., Perez, A., Petrigh, R., Zimmer, P., Alcaraz, E., Echaide, I., de Eschaide, Torioni., Kocan, K.M., De La Fuente, J., Farber, M., 2009. Genetic diversity of Anaplasma marginale in Argentina. Veterinary Parasitology 162, 176-180.

Sahibi, H., Rhalem, A., 2007. Tiques et maladies transmises par les tiques chez les bovins au Maroc. Bulletin mensuel d'information et de liaison du PNTTA 151, 14.

Sahibi, H., Rhalem, A., Berrag, B., Goff, W.L., 1998a. Bovine babesiosis. Seroprevalence and ticks associated with cattle from two different regions of Morocco. Annals of the New York Academy of Sciences 849, 213-218.

Sahibi, H., Rhalem, A., Berrag, B., Goff, W.L., 1998b. Seroprevalence of bovine anaplasmosis in Morocco. Annals of the New York Academy of Sciences 849, 427-429.

Scoles, G.A., Goff, W.L., Lysyk, T.J., Lewis, G.S., Knowles, D.P., 2008. Validation of an Anaplasma marginale cELISA for use in the diagnosis of $A$. bovis infections in domestic sheep and Anaplasma spp. in wild ungulates. Veterinary Microbiology $130,184-190$.

Stuen, S., van de Pol, I., Bergström, K., Schouls, L.M., 2002. Identification of Anaplasma phagocytophila (formerly Ehrlichia phagocytophila) variants in blood from sheep in Norway. Journal of Clinical Microbiology 40, 3192-3197.

Swai, E.S., Karimuribo, E.D., Ogden, N.H., French, N.P., Fitzpatrick, J.L., Bryant, M.J., Kambarage, D.M., 2005. Estimation and risk factors for A. marginale on small holder dairy farms in Tanzania. Tropical Animal Health and Production 37, 599610.

Torina, A., Alongi, A., Naranjo, V., Estrada-Pena, A., Vicente, J., Scimeca, S., Marino, A.M., Salina, F., Caracappa, S., De La Fuente, J., 2008. Prevalence and genotypes of Anaplasma species and habitat suitability for ticks in a Mediterranean ecosystem. Applied and Environment Microbiology 24, 7578-7584.

Torioni de Echaide, S., Knowles, D.P., McGuire, T.C., Palmer, G.H., Suarez, C.E., McElwain, T.F., 1998. Detection of cattle naturally infected with Anaplasma marginale in a region of endemicity by nested PCR and a competitive enzymelinked immunosorbent assay using recombinant major surface protein 5 . Journal of Clinical Microbiology 36, 777-782.

Ueti, M.W., Reagan, J.O., Knowles, D.P., Scoles, G.A., Shkap, V., Palmer, G.H., 2007. Identification of midgut and salivary glands as specific and distinct barriers to efficient tick-borne transmission of Anaplasma marginale. Infection and Immunity 75, 2959-2964.

Uilenberg, G., 1995. International collaborative research: significance of tick-borne hemoparasitic diseases to world animal health. Veterinary Parasitology 57, 1941.

Urdaz-Rodríguez, J.H., Fosgate, G.T., Alleman, A.R., Rae, D.O., Donovan, G.A., Melendez, P., 2009. Seroprevalence estimation and management factors associated with high herd seropositivity for Anaplasma marginale in commercial dairy farms of Puerto Rico. Tropical Animal Health Production 41, 1439-1448.

Verhulst, A., Mahin, L., Thys, E., De Witt, K.J., 1983. Prevalence of antibodies to Anaplasma marginale in cattle from various African biotopes in central Morocco, north Cameroon and southeastern Zaïre. Zentralblatt Veterinary 30, 537-540.

World Organization for Animal Health (OIE), 2008. Bovine anaplasmosis. In: Manual of Diagnostic Tests and Vaccines for Terrestrial Animals, 6th ed. OIE, Paris, France, pp. 599-610.

Younis, E.E., Hegazy, N.A.M., El-Deeb, W., El-Khatib, R.M., 2009. Epidemiological and biochemical studies on bovine anaplamosis in Dakahlia and Demiatta governorates in Egypt. Bulletin of Animal Health and Production in Africa 57 (4), 297-309.

Ziam, H., Benaouf, H., 2004. Prevalence of blood parasites in cattle from wilayates of Annaba and El Tarf east Algeria. Archives de l'Institut Pasteur de Tunis 81, 2730. 